\title{
sciendo
}

CIVIL AND ENVIRONMENTAL ENGINEERING REPORTS

E-ISSN 2450-8594

CEER 2018; 28 (2): 177-185

DOI: $10.2478 /$ ceer-2018-0028

Original Research Article

\section{A HYBRID METHOD OF DETERMINING DEFORMATIONS OF ENGINEERING STRUCTURES WITH A LASER STATION AND A 3D SCANNER}

\author{
Jacek SZTUBECKI ${ }^{1}$, Adam BUJARKIEWICZ ${ }^{1}$, Karol DEREJCZYK ${ }^{2}$, \\ Michał PRZYTUŁA ${ }^{2}$ \\ ${ }^{1}$ University of Technology and Life Sciences in Bydgoszcz, Bydgoszcz, Poland \\ ${ }^{2}$ TPI Sp. z o.o., ul. Bartycka 22, 00-716 Warszawa, Poland
}

\begin{abstract}
The article presents the technology and an analysis of results of engineering structure displacements and deformation measurements. Two measuring technologies using the TDRA65000 laser station from Leica and the FARO Focus M scanner were applied during the tests. Use of the laser station enabled us to define horizontal and vertical displacements of a control network established on the tested facility. Owing to this, it was also possible to transform scanner measuring stations into one integrated unit. The described measurement methodology ensures a high accuracy of scanner station fitting which translates directly into the accuracy of determination of deformations in structural components of a facility. Integration of methods applied in the tests makes it possible to monitor not only displacements of control network points but also the structure as a whole in a uniform coordinate system.
\end{abstract}

Keywords: geodetic measurement of displacements, laser scanning

${ }^{1}$ Corresponding authors: University of Technology and Life Sciences in Bydgoszcz, Faculty of Civil and Environmental Engineering and Architecture, Al. S. Kaliskiego 7, 85-796 Bydgoszcz, Poland, e-mail: jaceksz@utp.edu.pl, tel. +48661567541 


\section{INTRODUCTION}

Geodetic monitoring is applied to determine displacements and deformations of engineering structures, etc. It covers measurements, a further analysis of which is used to precise conclusions concerning the dynamics of structure changes. Furthermore, such measurements provide information on their geometric conditions and changes over time [3,4]. A basic symptom of unfavourable phenomena occurring in buildings are their displacements. They are monitored with a series of measurements of a network of measuring and control points established on the facility [5]. Contemporary measuring technologies are applied to fulfil tasks which could not be fulfilled with the traditional methods, while ensuring the required accuracy. Displacements and deformations of engineering structure constituents can be determined with modern laser devices. These technologies are often used in metrological industrial measurements and are distinguished with a very high distance measurement accuracy up to $+/-15 \mu \mathrm{m}+6 \mu \mathrm{m} / \mathrm{m}$ at retroreflector measurements and an operating range of $120 \mathrm{~m}[2,7]$. Furthermore, measurements conducted with such techniques are less labour intensive and less time consuming. They guarantee a higher precision and can be used to solve complex measurement tasks [6]. The article presents an analysis of results of building displacement measurements. Two measuring devices were used for this purpose: the TDRA 6000 coordinate laser station from Leica and a 3D scanner from FARO. The purpose of the tests was to check the possibility of combining two measuring technologies, allowing for effective determination of engineering structure deformations.

With obtained test results, we were able to draw conclusions on the possibility of using the above measuring technologies for this task and on the achieved accuracy.

\section{TESTED OBJECT}

The tests were conducted on a control network established inside an overhead skyway connecting buildings of the University of Science and Technology in Bydgoszcz. The skyway is of a reinforced concrete design supported on 12 columns. The view of the skyway is shown in Fig. 1.

Controlled points and stabilised reference points remained inside the skyway and the surrounding buildings in the form of washers fixed to the floor (Photo 2a). In order to present measurements carried out with the laser station and the scanner in a uniform coordinate system, adjustment points were arranged in the buildings adjacent to the skyway in the form of crosshairs fixed to the walls (Photo 2b). The layout of network points is shown in Fig. 1. 


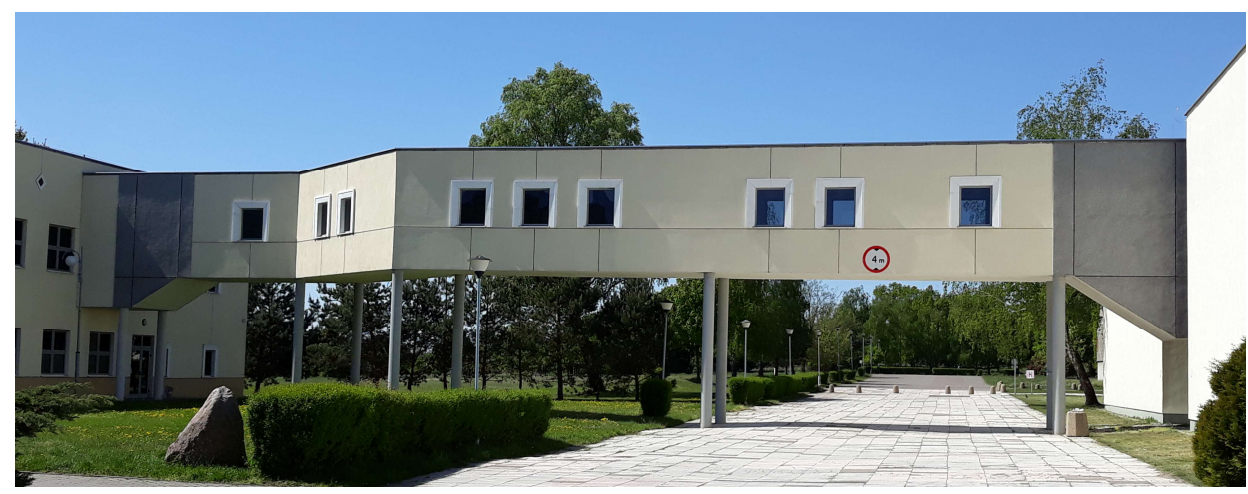

Fig. 1. The view of the skyway

a)

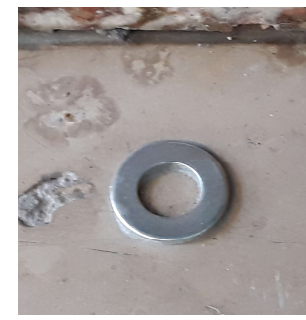

b)

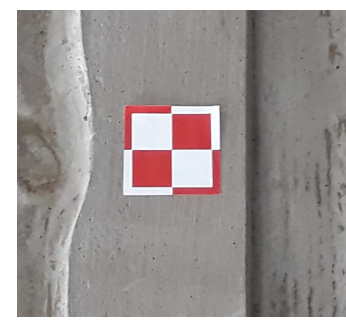

Photo 2. Network point stabilisation method controlled points, b) adjustment points

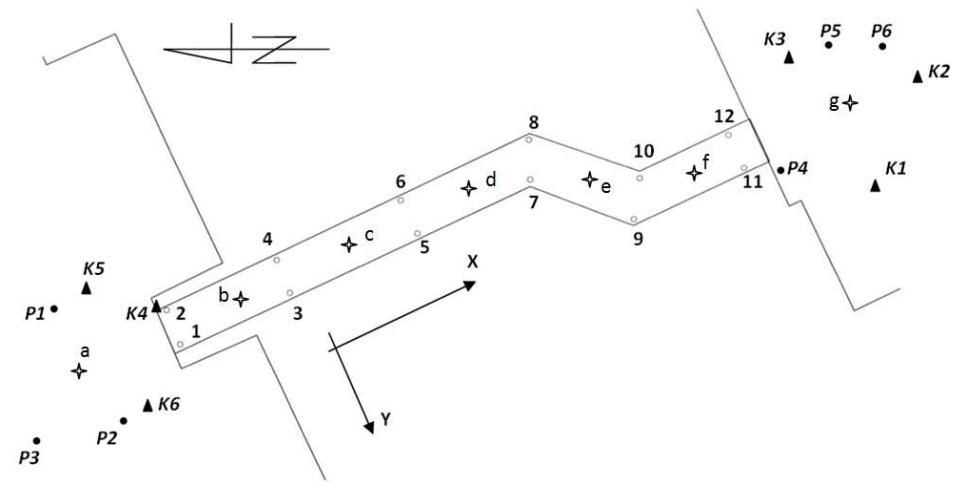

Fig. 1. Network point layout $(\mathrm{P} 1 \div \mathrm{P} 6$ - reference points, $1 \div 12-$ controlled points, $\mathrm{a} \div \mathrm{g}$ - laser station points, $\mathrm{K} 1 \div \mathrm{K} 6$ - adjustment points)

\section{METHODS}

The purpose of the tests was to check the possibility of using two measuring technologies allowing for determination of engineering structure deformation 
displacements. Two measuring devices were used for the tests: the TDRA6000 coordinate laser station from Leica and the 3D Faro Laser Scanner Focus M.

The TDRA6000 laser station features a direct drive technology ensuring a 3D point accuracy of $0.25 \mathrm{~mm}$ and can be used to observe horizontal and vertical directions with an average error of $0.0013^{\mathrm{g}}$ at a distance of $0.2 \mathrm{~mm}[1,8]$. The device with proper software is a perfect tool to monitor engineering facilities. The 3D Focus FARO scanner is characterised by a distance measurement accuracy of $\pm 1 \mathrm{~mm}$ and an angular accuracy of 19" [9].

Measurements of the network with the laser station involved recording 3D coordinates of controlled points on each of 7 free stands (a-g). Only the nearest control points were observed from each stand: for the outermost stands $(\mathrm{a}, \mathrm{g})-5$ points, for the remaining stands -4 points. Measurements were carried out twice. Calculations were made in two stages. At the first one, differences in elevation between the network points were calculated and then the network was subjected to rigorous adjustment. The second stage involved determination of horizontal displacements of the established network. Calculations were made with flat X, Y coordinates of the control points, applying isometric transformation integrating free stands and Helmert transformation on 6 adjustment points (P1-P6), the purpose of which was to present control point coordinates from individual measurement series in a uniform local coordinate system. Horizontal displacements of the points were determined by calculating differences of $\mathrm{X}$ and $\mathrm{Y}$ coordinates between measurement series.

Laser scanning measurements were carried out on 9 free stands. The first phase of data development involved gathering of point clouds into one set. After integrating free point clouds obtained from the stands into one set, it was transformed into a uniform system using the adjustment points. Adjustment point coordinates $(\mathrm{K} 1 \div \mathrm{K} 6)$ were specified in the process of calculation of laser station measurements. With such a calculation scheme, it was possible to determine coordinates of the controlled points and coordinates of the point clouds in a uniform coordinate system. This method provides an opportunity to perform cyclical measurements of a structure and determine its displacements and deformations.

\section{DISCUSSION OF THE RESULTS}

Four measurement series have been conducted so far with the laser station: measurement 0 - 21.07.2017, measurement 1 - 04.09.2017, measurement 2 10.11.2017, measurement $3-10.03 .2018$ and one with the scanner -06.03.2018. On the basis of the above measurements, it was possible to determine vertical displacements of the controlled points. Displacement errors specified in the 
process of their determination are a significant parameter for the assessment of utilisation of a laser station for such tasks. Obtained errors of determined vertical displacements are shown in Table 1.

Table 1. Values of errors of determined vertical displacements

\begin{tabular}{|c|c|c|c|}
\hline \multirow{3}{*}{ Point no. } & $\begin{array}{l}\text { Measurement 0 - } \\
\text { Measurement 1 }\end{array}$ & $\begin{array}{l}\text { Measurement 0 - } \\
\text { Measurement 2 }\end{array}$ & $\begin{array}{l}\text { Measurement 0 - } \\
\text { Measurement 3 }\end{array}$ \\
\cline { 2 - 4 } & $\mathrm{m}_{\mathrm{dZ}}[\mathrm{mm}]$ & $\mathrm{m}_{\mathrm{dZ}}[\mathrm{mm}]$ & 0.07 \\
\hline 1 & 0.07 & 0.06 & 0.07 \\
\hline 2 & 0.07 & 0.06 & 0.07 \\
\hline 3 & 0.07 & 0.07 & 0.07 \\
\hline 4 & 0.07 & 0.07 & 0.08 \\
\hline 5 & 0.08 & 0.07 & 0.08 \\
\hline 6 & 0.08 & 0.07 & 0.08 \\
\hline 7 & 0.08 & 0.07 & 0.08 \\
\hline 8 & 0.08 & 0.07 & 0.07 \\
\hline 9 & 0.07 & 0.07 & 0.07 \\
\hline 10 & 0.07 & 0.07 & 0.07 \\
\hline 11 & 0.07 & 0.06 & 0.07 \\
\hline 12 & 0.07 & 0.06 & \\
\hline
\end{tabular}

Analysing Table 1, one may notice that the obtained values of vertical displacement errors correspond to analogical values obtained when determining vertical displacements with the precise levelling method.

The analysis of an accuracy of determination of horizontal displacements in the first phase was based on determination of an isomorphic transformation error for each laser station stand. Values of these errors are shown in Table 2.

Table 2. Values of isometric transformation errors [mm]

\begin{tabular}{|c|c|c|c|c|}
\hline \multirow{2}{*}{ Stand } & \multicolumn{4}{|c|}{ Transformation error [mm] } \\
\cline { 2 - 5 } & $\begin{array}{c}\text { measurement } 0 \\
2017.07 .24\end{array}$ & $\begin{array}{c}\text { measurement } 1 \\
2017.09 .09\end{array}$ & $\begin{array}{c}\text { measurement } 2 \\
2017.11 .10\end{array}$ & $\begin{array}{c}\text { measurement 3 } \\
2017.03 .10\end{array}$ \\
\hline $\mathrm{a}$ & 0.11 & 0.08 & 0.16 & 0.13 \\
\hline $\mathrm{b}$ & 0.23 & 0.16 & 0.07 & 0.19 \\
\hline $\mathrm{c}$ & 0.20 & 0.21 & 0.31 & 0.06 \\
\hline $\mathrm{d}$ & 0.10 & 0.24 & 0.14 & 0.18 \\
\hline $\mathrm{e}$ & 0.15 & 0.08 & 0.09 & 0.27 \\
\hline $\mathrm{f}$ & 0.12 & 0.05 & 0.17 & 0.09 \\
\hline $\mathrm{g}$ & 0.28 & 0.19 & 0.14 & 0.21 \\
\hline
\end{tabular}


After integrating the stands, starting from the second measurement series, the network points were transformed to the system from the output measurement (measurement 0) using the reference points (P1-P6). For this purpose, the Helmert transformation was applied. Values of transformation errors are shown in the table below.

Table 3. Helmert transformation errors [mm]

\begin{tabular}{|c|c|c|}
\hline $\begin{array}{c}\text { Measurement } 0- \\
\text { Measurement } 1\end{array}$ & $\begin{array}{c}\text { Measurement 0- } \\
\text { Measurement 2 }\end{array}$ & $\begin{array}{c}\text { Measurement 0 - } \\
\text { Measurement 3 }\end{array}$ \\
\hline 0.49 & 0.76 & 0.88 \\
\hline
\end{tabular}

Scanner measurements conducted from 9 stands were added to the last measurement series involving laser station measurements. The view of the integrated point cloud is shown in Fig. 2.

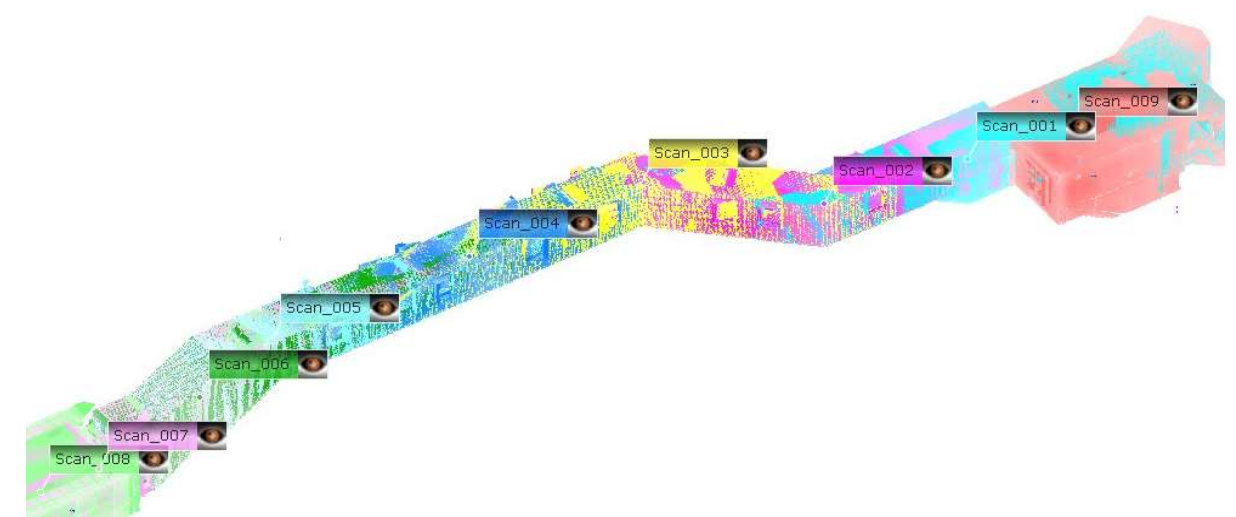

Fig. 2. The view of the integrated point cloud measured with the Focus scanner

In the process of connecting point clouds, maximum and average point measurement errors were determined (Table 4).

Table 4. Maximum and average point measurement error [mm]

\begin{tabular}{|c|c|c|}
\hline Stand & $\begin{array}{c}\text { Maximum point measurement } \\
\text { error }\end{array}$ & $\begin{array}{c}\text { Average point measurement } \\
\text { error }\end{array}$ \\
\hline Scan_001 & 0.7 & 0.6 \\
\hline Scan_002 & 1.4 & 0.9 \\
\hline Scan_003 & 0.7 & 0.7 \\
\hline Scan_004 & 1.9 & 1.3 \\
\hline Scan_005 & 1.2 & 1.0 \\
\hline Scan_006 & 1.8 & 1.1 \\
\hline Scan_007 & 1.9 & 1.2 \\
\hline Scan_008 & 0.7 & 0.7 \\
\hline Scan_009 & 1.4 & 1.0 \\
\hline
\end{tabular}


On the first and last stands in this measurement, the scanner recorded the position of the adjustment points $(\mathrm{K} 1 \div \mathrm{K} 6)$ whose spatial coordinates were determined also with the TDRA6000 laser station. On the basis of the adjustment point coordinates, the integrated point cloud was transformed into the system applied in the laser station measurement.

This process was completed for two variants. In the first one, the transformation was based on three adjustment points in the first scan, in the second one - all six points recorded in the first and last scans were used. Errors of individual adjustment points are shown in Table 5.

Table 5. Average adjustment point errors

\begin{tabular}{|c|c|c|c|c|}
\hline \multirow{2}{*}{ Stand } & \multicolumn{2}{|c|}{ Variant 1 } & \multicolumn{2}{c|}{ Variant 2 } \\
\cline { 2 - 5 } & $\begin{array}{c}\text { Horizontal } \\
\text { H [mm] }\end{array}$ & $\begin{array}{c}\text { Vertical V } \\
{[\mathrm{mm}]}\end{array}$ & $\begin{array}{c}\text { Horizontal H } \\
{[\mathrm{mm}]}\end{array}$ & $\begin{array}{c}\text { Vertical V } \\
{[\mathrm{mm}]}\end{array}$ \\
\hline K1 & 0.5 & 0.0 & 2.6 & 1.8 \\
\hline K2 & 0.6 & 0.0 & 2.8 & 1.2 \\
\hline K3 & 0.9 & 0.0 & 2.2 & 0.3 \\
\hline K4 & - & - & 2.5 & 1.5 \\
\hline K5 & - & - & 1.9 & 0.1 \\
\hline K6 & - & - & 3.0 & 1.7 \\
\hline
\end{tabular}

Analysing the values of errors for variant 1 , one can state that they fall within the scanner specification (below $1 \mathrm{~mm}$ ). However, they do not characterise the accuracy of the integrated point cloud. Moreover, as regards the geodetic measurement principles, such a one-sided reference is rarely applied.

Variant 2, in which adjustment points are in the first and last scans, provides information on the accuracy of the whole integrated cloud. Values of errors in this variant do not exceed $3 \mathrm{~mm}$.

\section{SUMMARY AND CONCLUSIONS}

The article presents an analysis of the results of building displacement measurements. The purpose of the tests was to check the possibility of using two measuring technologies allowing for effective determination of engineering structure deformations. The TDRA6000 coordinate laser station from Leica and the FARO 3D scanner were used in the above measurements.

On the basis of the analyses performed, the following conclusions have been drawn:

- Analysing errors specified in the process of determination of vertical displacements of the network of control points established inside the skyway, a high accuracy of the measurement was stated. Errors of determined displacements were $\max 0.08 \mathrm{~mm}$, which corresponds to accuracies obtained 
when applying the precise levelling method. The applied method may constitute an alternative to the precise levelling method used for vertical displacements.

- The accuracy analysis of the presented vertical displacement determination method was based on determination of errors of two types of transformations: isometric and Helmert. Both, errors of the isometric transformation for free stands (max $0.31 \mathrm{~mm}$ ) and errors of the Helmert transformation ( $\max 0.88 \mathrm{~mm}$ ) indicate a high accuracy.

- The analysis of measurements carried out with the scanner confirmed that the value of errors of adjustment points for a single stand did not exceed $1 \mathrm{~mm}$, which falls within the scanner specification.

- The variant of compilation of measurements obtained through the scanning, in which adjustment points were positioned in the first and last scans, provided information on the accuracy of the whole point cloud. The values of errors in this variant did not exceed $3 \mathrm{~mm}$.

The authors of this article are planning to carry out another series of measurements with the use of both measuring devices in the near future. Measurements will be used to determine displacements of permanently stabilised network points (measurements with the TDRA6000 station) and skyway internal surface deformations (measurements with the Focus scanner).

\section{REFERENCES}

1. Burge J.H., Peng Su, Chunyu Zhao, Zobrist T.: Use of a commercial laser tracker for optical alignment. Optical System Alignment and Tolerances, edited by José M. Sasian.

2. Golparvar-Fard M., Bohn J., Teizer J., Savarese S., Peña-Mora F.: Evaluation of image-based modelling and laser scanning accuracy for emerging automated performance monitoring techniques, Automation in Construction, Volume 20, 2011, Pages 1143-1155.

3. Kadaj R.: Modele, metody i algorytmy obliczeniowe sieci kinematycznych $w$ geodezyjnych pomiarach przemieszczeń $i$ odksztatceń obiektów, Wydawnictwo Akademii Rolniczej, Kraków 1998.

4. Lazzarini T.: Geodezyjne pomiary odksztatcen $i$ ich zastosowanie w budownictwie, PPWK, Warszawa 1961.

5. Mrówczyńska M., Gibowski S.: Indicating vertical deviation of historical buildings using geodetic methods - case study of brick and wood tower in Nowe Miasteczko, Civil and Environmental Engineering Reports, Volume 22, 2016, Pages 127-135. 
6. Sztubecki J., Mrówczyńska M. Bujarkiewicz A., Proposition of determination of displacements using the TDRA 6000 laser station, XXIII Autumn School of Geodesy, Wałbrzych 2018.

7. Wojcik G.J., Lakanen S. A.: Laser Tracker, a handy tool for metrology and alignment, Proceedings of the 7th International Workshops on Accelerator Alignment, SPring-8, Japan, 14 November 2002

8. https://metrology.leica-geosystems.com

9. https://www.faro.com/pl

\section{HYBRYDOWA METODA WYZNACZANIA ODKSZTALCEŃ KONSTRUKCJI INŻYNIERSKICH Z WYKORZYSTANIEM STACJI LASEROWEJ ORAZ SKANERA 3D}

\section{Streszczenie}

W artykule przedstawiono technologię oraz analizę wyników pomiaru przemieszczeń i odkształceń obiektu inżynierskiego. W trakcie badań zastosowano dwie technologie pomiarowe wykorzystujące stację laserową TDRA6000 firmy Leica oraz skaner FARO Focus M. Wykorzystanie stacji laserowej pozwoliło na wyznaczenie przemieszczeń poziomych i pionowych sieci kontrolnej założonej na badanym obiekcie oraz posłużyło do transformacji stanowisk pomiarowych skanera do jednolitego układu. Opisana metodologia pomiaru zapewnia wysokie dokładności wpasowania stanowisk skanera co przekłada się bezpośrednio na dokładność wyznaczenia odkształceń elementów konstrukcyjnych obiektu. Integracja zastosowanych w badaniach metod pozwala na monitorowanie nie tylko przemieszczeń punktów sieci kontrolnej, ale również konstrukcji jako całości w jednolitym układzie współrzędnych.

Słowa kluczowe: geodezyjny pomiar przemieszczeń, skaning laserowy

Editor received the manuscript: 21.06 .2018 